Original paper

\title{
HPLC-ESI-MS AND GC-EI-MS IDENTIFICATION AND QUANTITATION OF POLYPHENOLICS AND ALKALOIDS IN MOROCCAN JUJUBE HONEYS
}

\author{
Farid Khallouki ${ }^{1}$ \\ Mourad Akdad ${ }^{2}$ \\ Toufik Bouddine ${ }^{3}$ \\ Lhoussain Hajji ${ }^{3}$ \\ Robert W. Owen ${ }^{4 \star}$ \\ 'Division of Preventive Oncology, National Center for Tumor Diseases, Im \\ Neuenheimer Feld 460 and German Cancer Research Center (DKFZ), Im \\ Neuenheimer Feld 581, Heidelberg, Germany \\ 2Team of Physiology, Pharmacology and Endocrinology, Faculty of Sciences \& \\ Techniques, University Moulay Ismail, 52000, Errachidia, Morocco \\ ${ }^{3}$ Department of Biology, Faculty of Sciences, University Moulay Ismail, Meknes, \\ Morocco \\ ${ }^{4}$ German Cancer Research Center, Heidelberg, Germany \\ *corresponding author: r.owen19sheep52@gmail.com \\ Received: 06 February 2020; accepted: 14 September 2020
}

A bstract

The aim of this study was to determine the phytochemical content of Moroccan Jujube Honey and to establish the principal components of this staple Moroccan food, which contributes health benefit for the local population. Total phytochemical compounds as determined by analytical HPLC-ESI-MS in the honey extracts were $29.39 \pm 5.21 \mathrm{mg} / \mathrm{kg}$ (range 16.64-42.16) wet weight. The individual phytochemical compounds definitively identified by HPLC-DAD-ESI-MS in the Jujube honeys were the alkaloids: (I) 4-hydroxyquinoline glucoside, (II) 4-hydroxyquinoline and (V) kynurenic acid $(17.66 \pm 0.87 \mathrm{mg} / \mathrm{kg})$, and the phenolic compounds: (III) p-hydroxybenzoic acid, (IV) caffeic acid and (VI) methyl syringate $(11.73 \pm 0.50 \mathrm{mg} / \mathrm{kg})$. The structures were confirmed by GC-EI-MS apart from 4-hydroxyquinoline-glucoside. The major components were methyl syringate $(8.34 \pm 2.49$ $\mathrm{mg} / \mathrm{kg})$, 4-hydroxyquinoline $(6.61 \pm 3.23 \mathrm{mg} / \mathrm{kg})$ and kynurenic acid $(6.56 \pm 0.97 \mathrm{mg} / \mathrm{kg})$. The mean content of polyphenolic compounds $(11.73 \pm 0.50 \mathrm{mg} / \mathrm{kg})$ of Moroccan Jujube honeys compared favorably with those described for six Chinese Jujube honeys (2.49 $\mathrm{mg} / \mathrm{kg})$, five commercial Jujube honeys from different countries $(0.92 \mathrm{mg} / \mathrm{kg})$ and twelve Jujube honeys from Yemen $(25.71 \mathrm{mg} / \mathrm{kg}$ ). Reference studies did not identify alkaloids as components of Jujube honey, and therefore the phytochemical profile of Moroccan Jujube honey appears to be unique.

Keywords: 4-(1'-Hydroxy-1'-dimethyl) cyclohexa-1,3-diene-1 carboxylic acid-1gentobioside, 4-hydroxyquinoline glucoside, 4-hydroxyquinoline, Jujube honey, kynurenic acid, methyl syringate, phenolic acid

\section{INTRODUCTION}

Honey refers to the fluid, pasty or crystalized functional food collected by bees (Apis mellifera) from the flowers and blossom nectar as well as from sweet deposits (honeydew) of living plants that bees forage on, transform and store to ripen in their hive. There are many varieties of honey with different or- ganoleptic properties including color, texture, aroma and flavor (Cernak et al., 2012), which are dependent on flora type, geography and preparation techniques. According to Bogdanov, Ruoff, \& Persano (2004), the color of honey is also associated with its flavor. Honey mainly comprises mixture of glucose and fructose, which represents around $70 \%$ of the total mass, and contains other such substances as volatile 
organic and phenolic compounds, salts including potassium, enzymes (either of animal or plant origin) including diastases, invertase, catalase and glucose oxidase. Additionally, honey contains nitrogen compounds (e.g. Maillard reaction products, bioactive peptides and some alkaloids) as well as organic acids and vitamins (such as vitamins C, B1, B6, B9, riboflavin, nicotinic acid and pantothenic acid,) and other metabolites (Aliferis et al., 2010; Wang et al., 2014; Zha et al., 2016).

Historically, honey has been ascribed many properties, including wound healing and the amelioration of liver, cardiovascular and gastrointestinal problems. Ancient Egyptians, Greeks and Romans reported its effectiveness against bacterial infections, wounds and burns (Zulma \& Lulat, 1989). Honey has also been recommended for the treatment of tuberculosis (AsadiPooya, Pnjehshahin, \& Beheshti, 2003) and as a fortifying and invigorating agent (Descottes, 2009).

The wild Jujube Ziziphus lotus (L.) Lam. belongs to the Rhamnaceae familly and is especially encountered in arid and semi-arid regions of the Mediterranean area, throughout Libya to Morocco and southern European countries (Benammar et al., 2010). Its fruits contain appreciable amounts of cyclopeptides alkaloids termed lotusines (Ghedira et al., 1993; 1995).

A large body of literature associates honey metabolites with numerous biological functions. In particular Jujube honey treatment for twelve weeks significantly protects against hepatic disorders which are linked to chronic alcoholism. It also inhibits serum lipoprotein oxidation and reduces the impact of alcoholism on aspartate aminotransferase (AST) and alanine aminotransferase (ALT), two enzyme levels valuable primarily in the diagnosis of liver diseases. Moreover, Cheng et al. (2014) observed an inhibition of the generation of 8-hydroxy-2-deoxyguanosine (8-OHdG), a decreased malondialdehyde (MDA) concentrations and increased hepatic glutathione peroxidase (GSH-Px) activity. In other recent reports, natural Jujube honeys from Buraidah and Najran of northcentral and southwestern Saudi Arabia, respectively, were screened and showed significant antibacterial effects particularly against gram positive bacterial strains. According to this report, the antibacterial characteristics of honey may be influenced by the area from which it was collected (Emad \& Arafa, 2019). Furthermore, anticancer effects which entail apoptotic mechanism via DNA damage, p53 expression, and caspase activation by Jujube honey in HepG2 cells have been reported (Cheng et al., 2019).

From a phytochemical point of view, Algerian Jujube honeys were characterized by their organoleptic and physicochemical properties including high values of electrical conductivity, potassium, calcium, pH, phenol content, amber color and medium protein content. From a palynological point of view, the presence of some pollen types in the pollen spectra of such honeys as Peganum harmala, Lotus, Eucalyptus, Taraxacum, Cistus, Trifolium, Carduus and Matricaria was proposed as a geographical indicator of this honey type (Zerouk et al., 2018). Yemeni Jujube honey has a total of twenty-five compounds (ten phenolic acids, nine flavonoids and six monophenols) (Badjah Hadj Ahmed et al., 2014) and polyphenolics including 4-hydroxybenzoic and cinnamic acid as well as chrysin at concentrations of $1.41 \mathrm{mg} / 100 \mathrm{~g}$, $1.34 \mathrm{mg} / 100 \mathrm{~g}$ and $0.85 \mathrm{mg} / 100 \mathrm{~g}$, respectively. In Jujube honey varieties from other arid Asian regions including Yemen, the content of the phenolic compounds identified clearly differed from those of non-arid regions with higher polyphenolic levels and their bioactivities (Habib et al., 2014).

To date, the scientific literature on the chemical composition of Moroccan honeys is very sparse despite total Moroccan honey production being estimated at 5,815 tons in 2015. As part of the dynamics of the Morocco Green Plan (Plan Maroc Vert), a development program contract between the beekeeping associations and the Moroccan Government was established for the period of 2011-2020.

The region of Errachidia (Tafilalt, Southeast of Morocco), is a well-known source of Jujube honey, which is in high demand due to its medicinal properties, taste, flavor and fragrance. Because 
there is a paucity of data, the aim of this pilot study was to evaluate the polyphenolic content of Moroccan Jujube honeys. The Jujube honeys studied here also contain appreciable levels of alkaloids and so were compared with a chestnut (Castanea sativa Mill.) honey produced in Italy, which is also renowned for its high alkaloid content.

\section{MATERIAL AND METHODS}

\section{Chemicals and reagents}

Acetic acid, acetonitrile and methanol were obtained from E. Merck (Darmstadt, Germany). 4-hydroxyquinoline and kynurenic acid and $\mathrm{N}$ methyl- $N$-(trimethylsilyl)-trifluoroacetamide (BSTFA) were obtained from Sigma-Aldrich Chemie (Deisenhofen, Germany). Caffeic acid, chrysin, $p$-coumaric acid, $p$-hydroxybenzoic acid, ferulic acid, methyl syringate, naringenin, syringic acid and pinocembrin were obtained from Extrasynthese (Lyon Nord, Genay, France) and Sep-Pak C18 cartridges for solid-phase extraction (Supelclean ${ }^{\mathrm{TM}}$ LC-18 SPE in 6-ml tubes, 500 and 5000 mg; Supelco, Bellefonte, Pennsylvania, USA). All solutions were made up in either double-distilled water, or methanol, unless otherwise stated.

\section{Honey samples}

Three commercial monofloral jujube honeys ( $\mathrm{H} 1$, $\mathrm{H} 2$ and $\mathrm{H} 3$ ) (Ziziphus lotus L.) harvested in 2018 were evaluated. The $\mathrm{H} 1, \mathrm{H} 2$ and $\mathrm{H} 3$ samples were collected from the El Khayr association of beekeepers at Kasbat Rahba Lkdima, Errachidia, Morocco (Latitude 3155'31": Longitude $4^{\circ} 25^{\prime} 41^{\prime \prime}:$ : Altitude 1241 metres). They harvested the honey by a manual extractor, after the foraging of the bees during the Jujube flowering periods. The El khayr association, the leader in honey commercialization in the Errachidia province, has commercialized different honey types through the practice of transhumance to other areas of Morocco.

A fourth Jujube honey sample (H4) was collected in 2018 from beekeepers of the Manahil Ikarama association who harvest honey by a manual extractor, after the foraging of the bees in the region of Er-Rich city, Morocco (Latitude 3115'28": Longitude 4²9'42": Altitude 1409 metres) during the Jujube flowering periods. Commercial Chestnut (Castanea sativa Mill.) honey (H5) was purchased from a local supermarket in Heidelberg, Germany (Der Klassiche Breitsamer honig: Kastania-Edelherb: produced in Italy (L6484151). Sell by date 10/2020).

\section{Preparation of extracts}

Duplicate Jujube and Chestnut honeys ( 2 × $10 \mathrm{~g}$ ) were completely dissolved in double- distilled water, made up to exactly $50 \mathrm{~mL}$ in volumetric flasks, and initially analysed directly by HPLCESI-MS. Clean-up of the extracts was achieved through fractionation on SPE, C18 Sep-Pak cartridges.

\section{Column chromatography on C18 Sep-Pak cartridges}

Diluted honey samples $10 \mathrm{~g}$ in double-distilled water $(50 \mathrm{~mL})$, were applied to C18 Sep-Pak cartridges $(5000 \mathrm{mg})$ for fractionation. The columns were preconditioned with methanol $(50.0 \mathrm{~mL})$, and distilled water $(50.0 \mathrm{~mL})$ and were not allowed to dry. Elution was performed with solvent mixtures $(50.0 \mathrm{~mL})$ containing increasing concentrations of methanol (5-50\%) in $2 \%$ acetic acid followed by $100 \%$ methanol. The solvent was removed by lyophilization prior to spectroscopic analyses.

\section{HPLC-DAD-ESI-MS}

HPLC-ESI-MS was conducted on an Agilent 1100 HPLC coupled to an Agilent single-quadrupole mass-selective detector (HP 1101; Agilent Technologies, Waldbronn, Germany). Honeys dissolved in double distilled water, or SPE fractions dissolved in methanol, were chromatographically separated using a column of the same type and dimensions as for analytical HPLC (Phenomenex, Aschaffenburg, Germany). Mobile phase- 1 consisted of $2 \%$ acetic acid in double- distilled water (solvent $A$ ) and acetonitrile (solvent $B$ ), with the gradient profile of initially $95 \% A$ for 10 min., to $90 \%$ A over 1 min., to $80 \%$ A over 9 min., to $60 \%$ A over 10 min., to $40 \%$ A over 10 min., to $0 \% A$ over 5 min and 
continuing at $0 \% \mathrm{~A}$ until completion of the run. Mobile phase-2 consisted of $2 \%$ acetic acid in doubly distilled water (solvent $A$ ) and methanol (solvent $B$ ) with the gradient profile of initially 95\% A for 2 min., to $75 \% \mathrm{~A}$ in $8 \mathrm{~min}$., to $60 \% \mathrm{~A}$ in $10 \mathrm{~min}$., to $50 \% \mathrm{~A}$ in $10 \mathrm{~min}$., to $0 \% \mathrm{~A}$ in $5 \mathrm{~min}$. and continuing at $0 \% \mathrm{~A}$ until completion of the run.

Phenolic compounds were detected by their UV absorbance $(A)$ at 257, 278, 320 and 340 $\mathrm{nm}$ at $30^{\circ} \mathrm{C}$. Negative-ion mass spectra were generated under the conditions of fragmentor voltage, 100 ; capillary voltage, $2500 \mathrm{~V}$; nebulizer pressure, 30 psi; drying gas temperature, $350^{\circ} \mathrm{C} ; \mathrm{m} / \mathrm{z}$ scan range, $100-1500 \mathrm{D}$. Positive-ion spectra were generated under the conditions of fragmentor voltage, 200; capillary voltage, $1500 \mathrm{~V}$; nebulizer pressure of 30 psi, drying gas temperature of $350^{\circ} \mathrm{C}$ and $\mathrm{m} / z$ scan range of 100-1500 D. For HPLC-ESI-MS-MS experiments in negative-ion mode, the fragmentor voltage was increased to 300 . Instrument control and data handling were performed on a personal computer with the Chemstation software.

\section{Semi-preparative HPLC}

Semi-preparative HPLC was conducted on a HP 1100 liquid chromatograph (Agilent Technologies, Waldbronn, Germany) fitted with a Zorbax Phenyl-Hexyl reverse-phase $(9.4$ x $250 \mathrm{~mm})$ C18 column (Agilent Technologies, Waldbronn, Germany). For the separation of individual compounds in the diluted Castanea sativa Mill. honey, the mobile phase $(3 \mathrm{~mL} / \mathrm{min})$ consisted of $2 \%$ acetic acid in water (solvent $A$ ) and acetonitrile (solvent B), utilizing the following solvent gradient profile over a total run time of $50 \mathrm{~min}$.: initially $95 \%$ A for 10 min.; reduced to $90 \% A$ over 1 min.; to $80 \%$ A over 9 min.; to $60 \%$ A over 10 min.; to $40 \%$ A over 10 min. and continuing at $0 \% \mathrm{~A}$ until completion of the run. Phytochemicals were detected by their UV absorbance $(A)$ at 257, 278305 and $340 \mathrm{~nm}$ at $30^{\circ} \mathrm{C}$. Peaks eluting from the column were collected on a HP 220 Microplate Sampler and subsequently lyophilized.

\section{Gas-chromatogaphy mass spectrometry (GC-MS)}

Analyses were performed on a HP 5973 mass spectrometer coupled to a HP 6890 gas chromatograph in the El scan mode. Prior to GC-MS, TMS ether derivatives were prepared by reaction with BSTFA $(100 \mu \mathrm{L})$ at $60^{\circ} \mathrm{C}$ for 30 minutes. Sample volumes of $1 \mu \mathrm{L}$ were injected into the GC-MS. Separation of the analytes was achieved using a HP 5MS capillary column, (30 m $\times 0.25 \mathrm{~mm}$ I.D., $0.25 \mu \mathrm{m}$ film thickness). Helium was used as carrier gas with a linear velocity of $0.9 \mathrm{~mL} / \mathrm{minute}$. The oven temperature program was an initial temperature of $160^{\circ} \mathrm{C}, 160^{\circ} \mathrm{C}$ to $270^{\circ} \mathrm{C}$ at $4^{\circ} \mathrm{C} /$ minute and $270^{\circ} \mathrm{C}$ for 20 minutes. The $\mathrm{GC}$ injector temperature was $250^{\circ} \mathrm{C}$; and the transfer line temperature was held at $280^{\circ} \mathrm{C}$. The mass spectrometer parameters for $\mathrm{El}$ mode were ion source temperature at $230^{\circ} \mathrm{C}$, electron energy at $70 \mathrm{eV}$, filament current at $34.6 \mu \mathrm{A}$ and electron multiplier voltage at $1200 \mathrm{~V}$.

\section{Standard curves}

The amounts of 4-hydroxyquinoline (II), $p$-hydroxybenzoic acid (III), caffeic acid (IV), kynurenic acid (V) and methyl syringate (VI) in the Jujube honeys were calculated from the HPLC-DADESI-MS standard curves of authentic standards in the range of $50-1000 \mu M$ at $278,257,320$ and $340 \mathrm{~nm}$ respectively. In the case of the 4-hydroxyquinoline glucoside (I), the concentration was calculated against the standard curve of 4-hydroxyquinoline with a relevant molecular weight correction.

The amounts of caffeic acid (IX) and p-coumaric acid $(\mathbf{X})$ in the diluted Castanea sativa Mill. honey were calculated from the HPLC-DAD-ESI-MS standard curves of authentic standards in the range $50-1000 \mu$ at $278,257,320$ and $340 \mathrm{~nm}$ respectively. Likewise the kynurenic acid derivatives in the diluted Castanea sativa Mill. honey namely 3-pyrrolinyl-kynurenic acid (3-PKA) (VIII), (XI), kynurenic acid tautomer (XII), gamma-lact-3-PKA (XIII), and kynurenic acid (XIV) were calculated from the HPLC-DAD-ESI-MS standard curve of kynurenic acid with relevant molecular weight corrections. The amounts of 4-(1'-hydroxy-1'-dimethyl)cyclohexa-1,3-di- 
ene-1 carboxylic acid-1-gentobioside (VII) and 4-(1'-hydroxy-1'-dimethyl)cyclohexa-1,3-diene-1 carboxylic acid-1 (XI) were calculated from a standard curve of 4-(1'-hydroxy-1'-dimethyl) cyclohexa-1,3-diene-1 carboxylic acid-1-gentobioside (VII) purified by semi-preparative HPLC with a molecular weight correction for the evaluation of 4-(1'-hydroxy-1'-dimethyl)cyclohexa-1,3-diene-1 carboxylic acid-1 (XI). Data are expressed in $\mathrm{mg} / \mathrm{kg}$ wet weight. All the standard curves showed $\mathrm{R}^{2}>0.99$.

\section{RESULTS}

Six major compounds were detected through HPLC-ESI-MS in the raw dilutions of Jujube honey of Moroccan origin (H1-H4) comprising alkaloids, and phenolic acids (Fig.1). These were the alkaloids, 4-hydroxyquinoline glycoside (I) 4-hydroxyquinoline (II) and kynurenic acid (V), the phenolic acids p-hydroxybenzoic acid (III) and caffeic acid (IV) and methyl syringate (VI). The compounds were identified by HPLCESI-MS (Figs. 2-4) in an negative ion mode (Tab. 1) following fractionation on Sep-Pak C18 cartridges and suspension of the lyophilised fractions in methanol $(2.0 \mathrm{~mL})$ and confirmed by GC-EI-MS (Tab. 2) as their trimethylsilyl ether derivatives. The levels of individual compounds in the Jujube honeys are shown in Tab. 3. On average a total of $29.39 \pm 5.21$ (range 16.6442.16) $\mathrm{mg} / \mathrm{kg}$ were quantitated in the Jujube honeys. The proportions of the polyphenolic species were alkaloids (58\%) and phenolic acids (42\%).

In the raw dilution of the Castanea sativa Mill. honey (H5), eight compounds were detected (five major and three minor). These were again identified by HPLC-ESI-MS (Fig. 5) as 4-(1'-hydroxy-1'-dimethyl)cyclohexa-1,3-diene-1 carboxylic acid-1-gentobioside (VII), 3-pyrrolinyl-kynurenic acid (3-PKA) (VIII), caffeic acid (IX), p-coumaric acid (X), 4-(1'-hydroxy1'-dimethyl)cyclohexa-1,3-diene-1 carboxylic acid-1 (XI), kynurenic acid tautomer (XII), gamma-lact-3-PKA (XIII), and kynurenic acid (XIV). The individual levels of compounds in the Castanea sativa Mill honey are also shown in Tab. 3. The proportions of the polyphenolic species were alkaloids (77\%) and terpenoids (23\%). The structures of the secondary metabolites detected in the Jujube and Castanea sativa Mill. honey samples are given in Figs. 6 and 7 respectively.

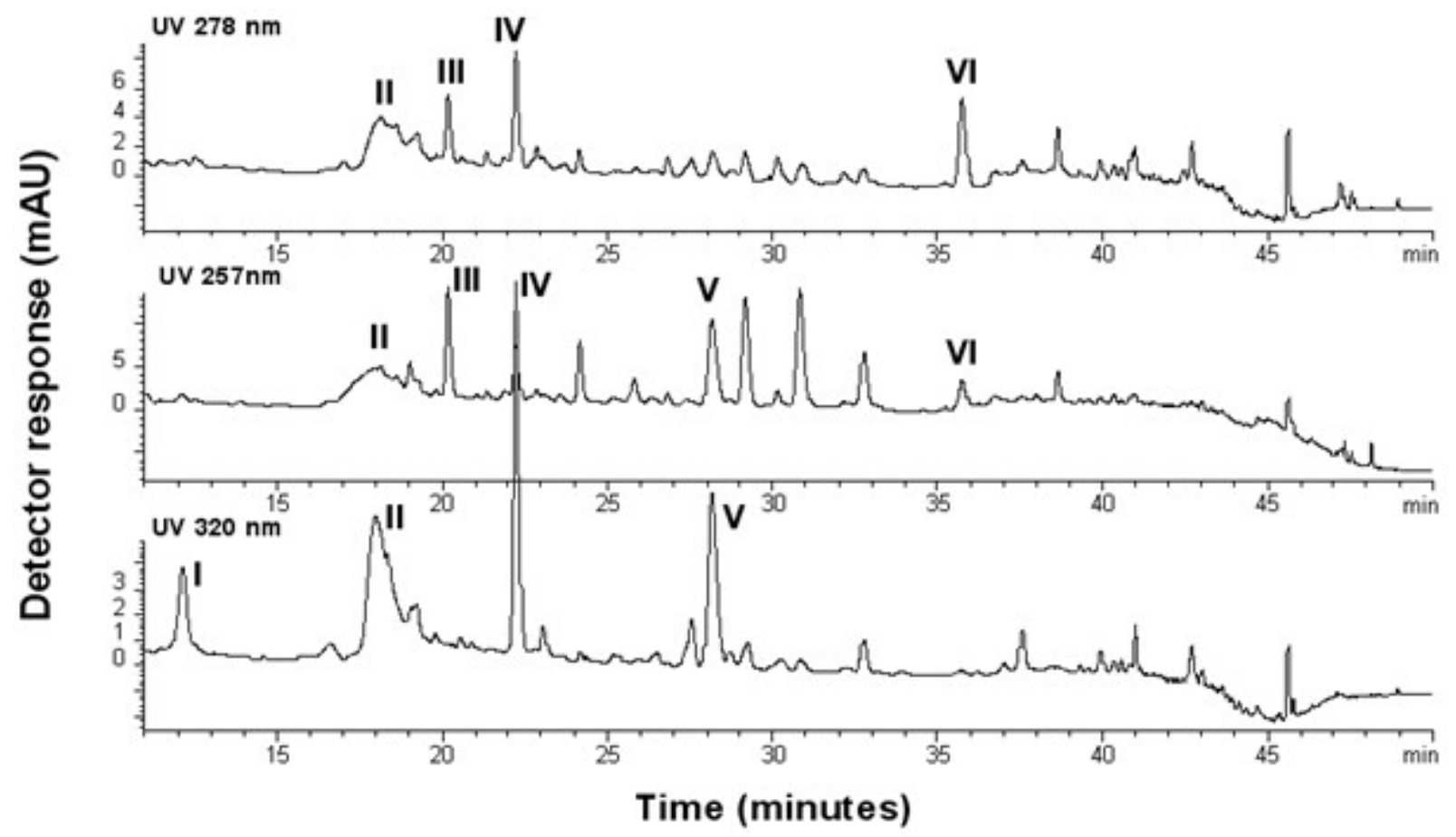

Fig. 1. Analytical HPLC-DAD-ESI-MS chromatogram (at 278, 257 and $320 \mathrm{~nm}$ ) of a Moroccan Jujube (Ziziphus lotus) honey $(10 \mathrm{~g})$ dissolved in doubly distilled water $(50.0 \mathrm{~mL})$ I. 4-hydroxyquinoline glucoside, II. 4-hydroxyquinoline, III. p-hydroxybenzoic acid, IV. caffeic acid, V. kynurenic acid, Vl. methyl syringate. 


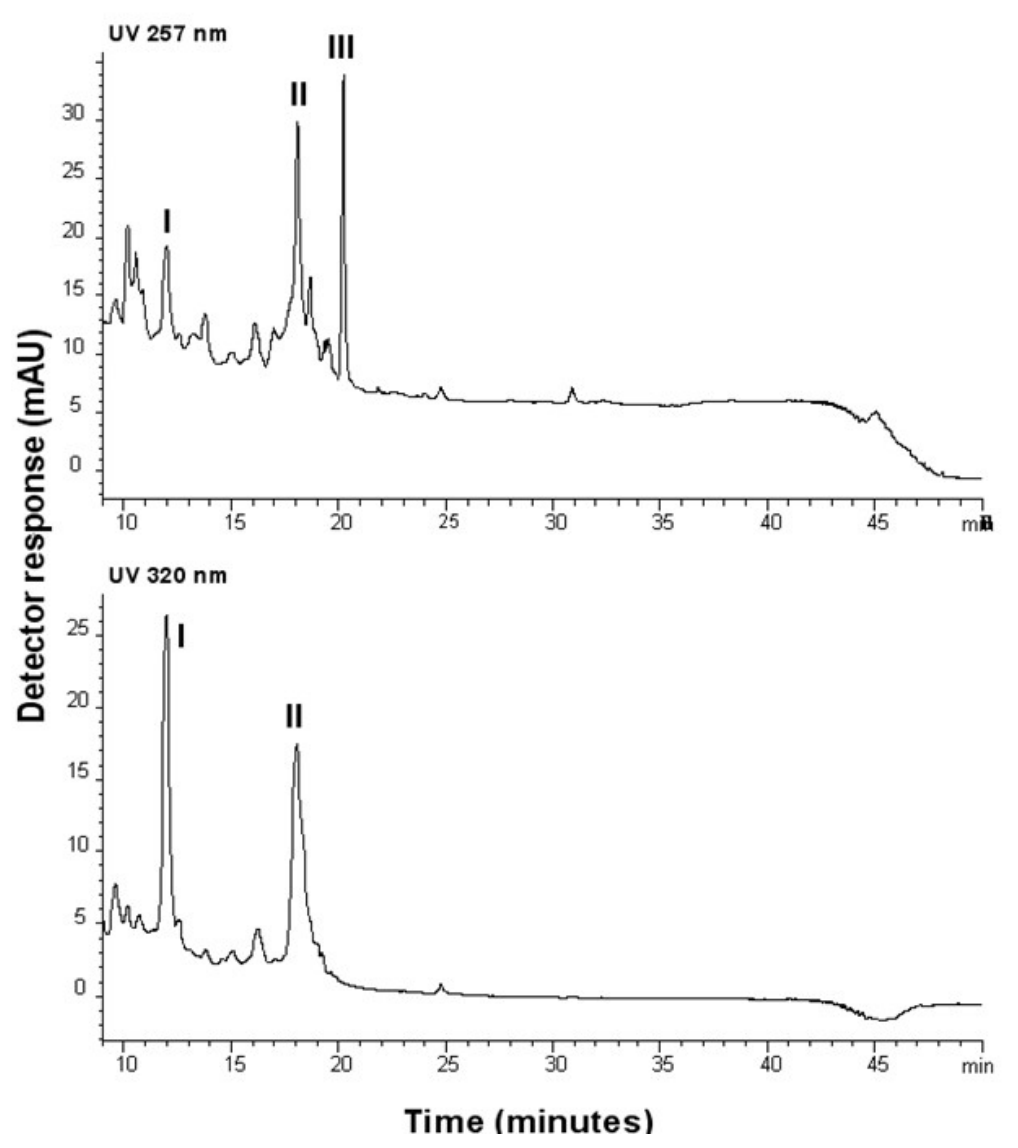

Fig. 2. Analytical HPLC-DAD-ESI-MS chromatogram (at 257 and $320 \mathrm{~nm}$ ) of a SPE (10\% methanol) fraction of Moroccan Jujube (Ziziphus lotus) honey (10g) I. 4-hydroxyquinoline glucoside, II. 4-hydroxyquinoline, III. p-hydroxybenzoic acid.

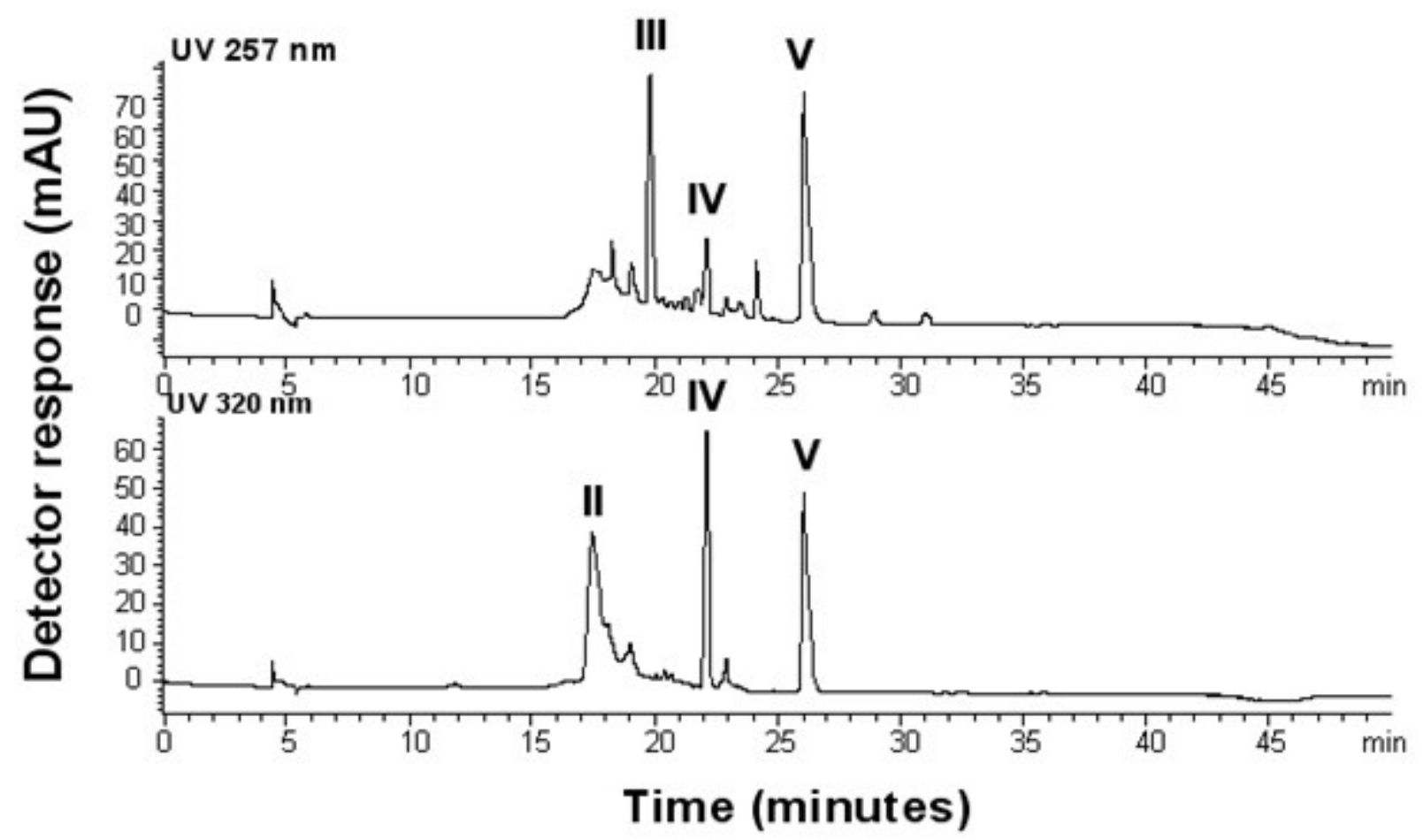

Fig. 3. Analytical HPLC-DAD-ESI-MS chromatogram (at 257 and $320 \mathrm{~nm}$ ) of a SPE (25\% methanol) fraction of Moroccan Jujube (Ziziphus lotus) honey (10 g) II. 4-hydroxyquinoline, III. p-hydroxybenzoic acid, IV. caffeic acid, V. kynurenic acid. 


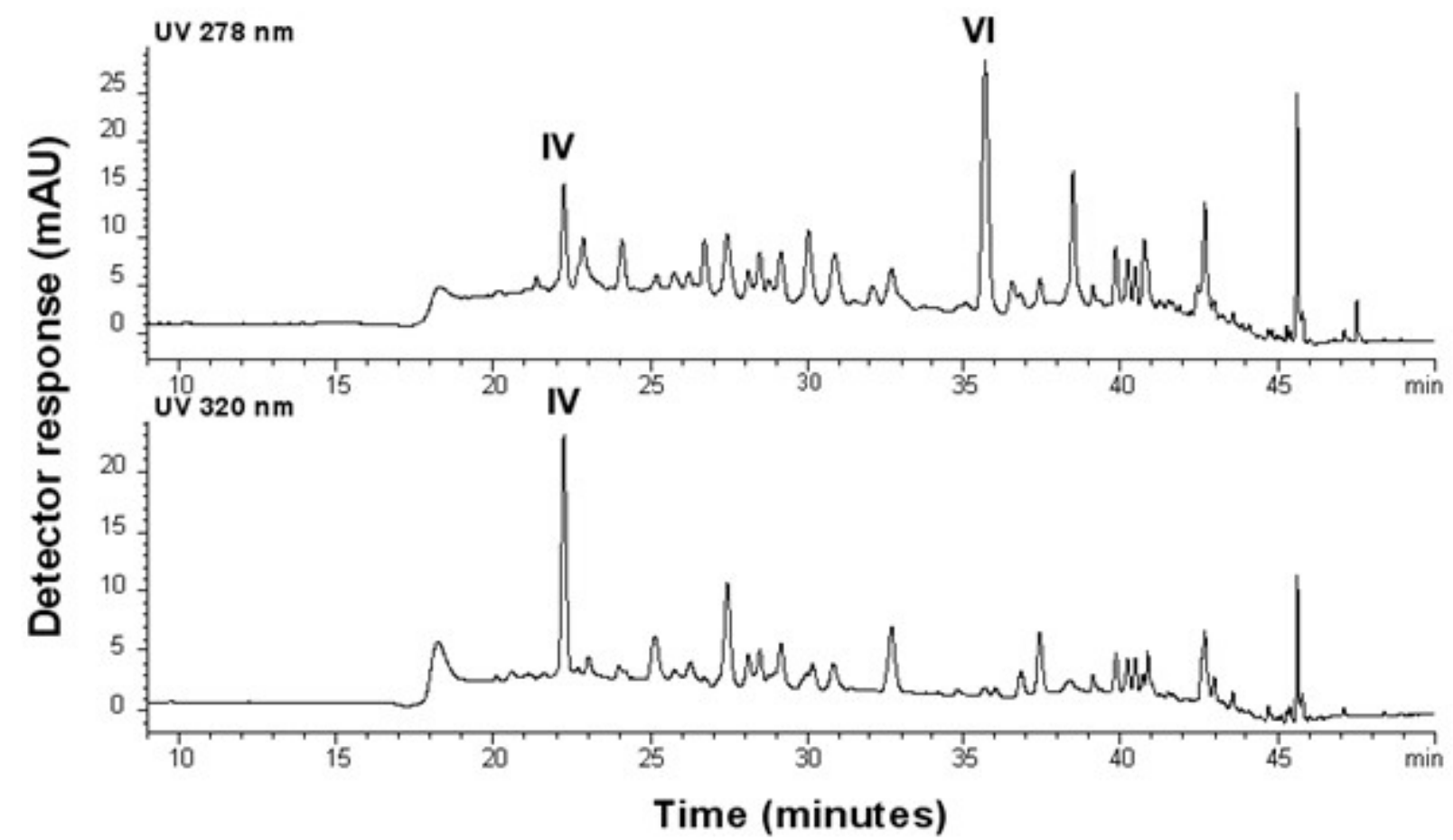

Fig. 4. Analytical HPLC-DAD-ESI-MS chromatogram (at 257 and $320 \mathrm{~nm}$ ) of a SPE (100\% methanol) fraction of Moroccan Jujube (Ziziphus lotus) honey (10 g) VI. methyl syringate.

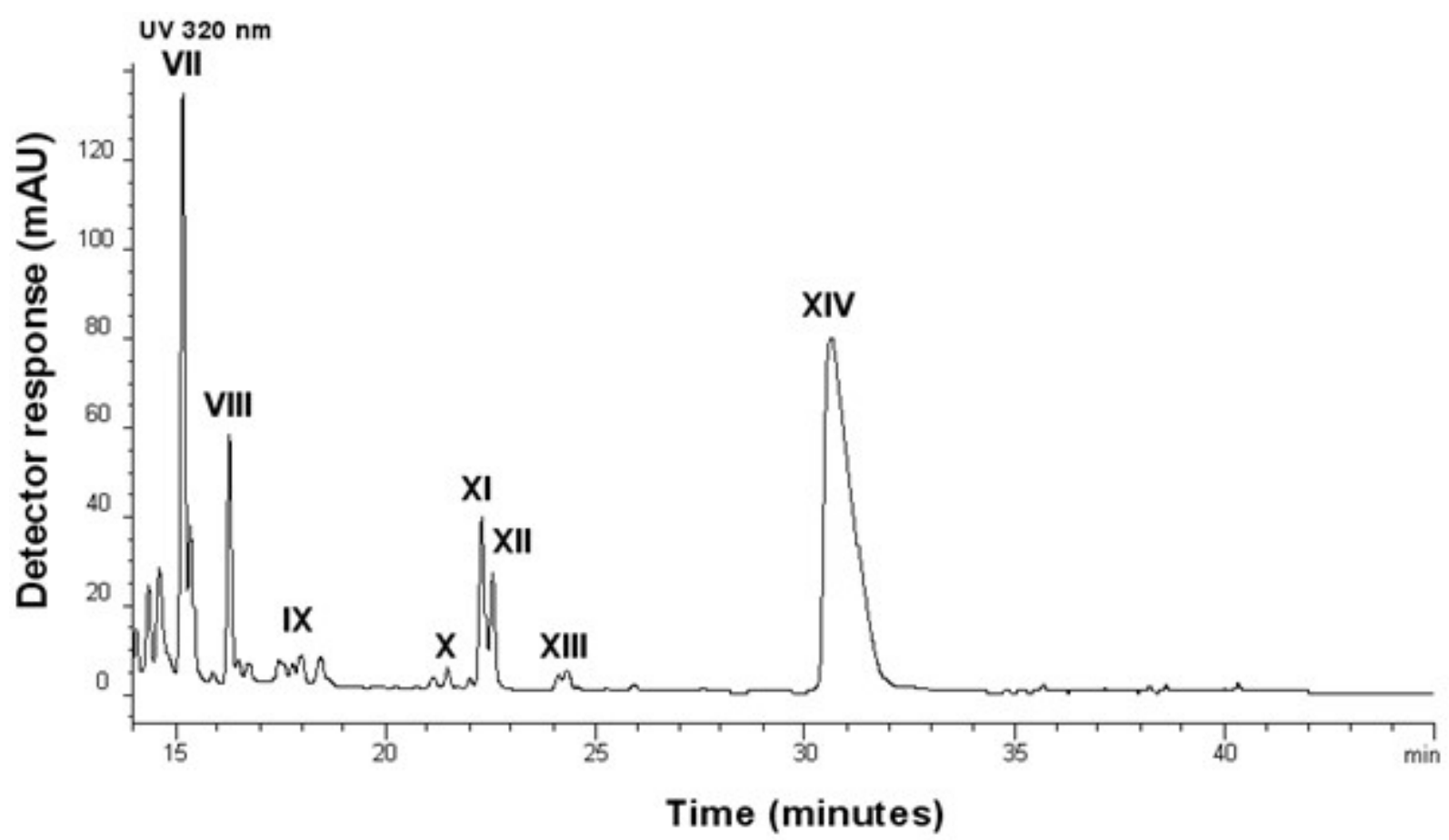

Fig. 5. Analytical HPLC-DAD-ESI-MS chromatogram (at $320 \mathrm{~nm}$ ) of an Italian Chestnut (Castania sativa Mill.) honey $(10 \mathrm{~g})$ dissolved in doubly distilled water $(50.0 \mathrm{~mL})$ VII. 4-(1'-hydroxy-1'-dimethyl)cyclohexa-1,3-diene-1 carboxylic acid-1-gentobioside, VIII. 3-pyrrolinyl-kynurenic acid (3-PKA), IX. caffeic acid, X. p-coumaric acid, XI. 4-(1'-hydroxy-1'-dimethyl)cyclohexa-1,3-diene-1 carboxylic acid-1, XII. kynurenic acid tautomer, XIII. gamma-lact-3-PKA, XIV. kynurenic acid. 
<smiles>OCC1C(O)OC(Oc2ccnc3ccccc23)C(O)C1O</smiles><smiles>Oc1ccnc2ccccc12</smiles><smiles>O=C(O)c1ccc(O)cc1</smiles><smiles>O=C(O)/C=C/c1ccc(O)c(O)c1</smiles><smiles>O=C(O)c1cc(O)c2ccccc2n1</smiles><smiles>COC(=O)c1cc(OC)c(O)c(OC)c1</smiles>

Fig. 6. Structures of the phenolic compounds detected and identified in Moroccan Jujube (Ziziphus lotus) honeys I. 4-hydroxyquinoline glucoside, II. 4-hydroxyquinoline, III. p-hydroxybenzoic acid, IV. caffeic acid, V. kynurenic acid, VI. methyl syringate.

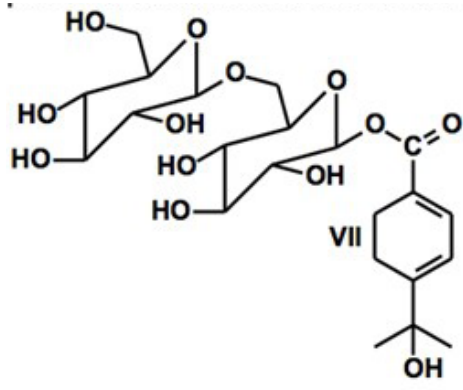<smiles>O=C(O)c1nc2ccccc2c(O)c1C1CCCN1</smiles><smiles></smiles><smiles>O=C(O)/C=C/c1c[X]c(O)cc1</smiles><smiles>[Y4]C(C)(C)c1ccc(C(=O)O)cc1</smiles><smiles>O=C1CC(C(=O)O)Nc2ccccc21</smiles><smiles>O=C1c2nc3ccccc3c(O)c2C2CCCN12</smiles><smiles>O=C(O)c1cc(O)c2cccnc2n1</smiles>

Fig. 7. Structures of the major polyphenolic compounds identified in Italien chestnut (Castania sativa Mill.) honey VII. 4-(1'-hydroxy-1'-dimethyl)cyclohexa-1,3-diene-1 carboxylic acid-1-gentobioside, VIII. 3-pyrrolinyl-kynurenic acid (3-PKA), IX. caffeic acid, X. p-coumaric acid, XI. 4-(1'-hydroxy-1'-dimethyl)cyclohexa-1,3-diene-1 carboxylic acid-1, XII. kynurenic acid tautomer, XIII. gamma-lact-3-PKA, XIV. kynurenic acid. 
Table 1.

HPLC-ESI-MS data in negative ion mode at a fragmentor voltage (100 V) of polyphenolic, alkaloid and terpenoid compounds detected in Jujube and Chestnut honey extracts

\begin{tabular}{|c|c|c|c|c|c|c|}
\hline Number & Phenolic compound & $\begin{array}{l}\text { Molecular } \\
\text { formula }\end{array}$ & $\begin{array}{c}\mathrm{R}_{\mathrm{t}} \\
(\mathrm{min})\end{array}$ & $\begin{array}{c}\text { Molecular } \\
\text { weight (exact) }\end{array}$ & {$[\mathrm{M}-\mathrm{H}]^{-}$} & {$[2 \mathrm{M}-\mathrm{H}]$} \\
\hline \multicolumn{7}{|c|}{ Jujube honeys (Morocco)* } \\
\hline I & $\begin{array}{l}\text { 4-Hydroxyquinoline } \\
\text { glucoside }\end{array}$ & $\mathrm{C}_{15} \mathrm{H}_{17} \mathrm{NO}_{6}$ & 11.97 & 307.106 & 306.2 & 613.1 \\
\hline II & 4-Hydroxyquinoline & $\mathrm{C}_{9} \mathrm{H}_{7} \mathrm{NO}$ & 17.45 & 145.053 & 144.2 & 289.1 \\
\hline III & $\begin{array}{l}p \text {-Hydroxybenzoic } \\
\text { acid }\end{array}$ & $\mathrm{C}_{7} \mathrm{H}_{6} \mathrm{O}_{3}$ & 19.82 & 138.032 & 137.2 & 275.2 \\
\hline IV & Caffeic acid & $\mathrm{C}_{9} \mathrm{H}_{8} \mathrm{O}_{4}$ & 22.11 & 180.042 & 179.1 & 359.1 \\
\hline V & Kynurenic acid & $\mathrm{C}_{10} \mathrm{H}_{7} \mathrm{NO}_{3}$ & 26.03 & 189.043 & 188.1 & 377.1 \\
\hline VI & Methyl syringate & $\mathrm{C}_{10} \mathrm{H}_{12} \mathrm{O}_{5}$ & 35.69 & 212.068 & 211.1 & 423.0 \\
\hline \multicolumn{7}{|c|}{ Chestnut honey (Italy)\# } \\
\hline VII & $\begin{array}{c}\text { 4-(1'-Hydroxy- } \\
\text { 1'-dimethyl) cy- } \\
\text { clohexa-1,3-diene-1 } \\
\text { carboxylic acid- } \\
\text { 1-gentobioside }\end{array}$ & $\mathrm{C}_{22} \mathrm{H}_{34} \mathrm{O}_{13}$ & 15.18 & 505.199 & 505.2 & 1011.4 \\
\hline VIII & 3-PKA & $\mathrm{C}_{14} \mathrm{H}_{14} \mathrm{~N}_{2} \mathrm{O}_{3}$ & 16.28 & 258.100 & 257.1 & n.d. \\
\hline IX & Caffeic acid & $\mathrm{C}_{9} \mathrm{H}_{8} \mathrm{O}_{4}$ & 17.99 & 180.042 & 179.1 & 359.1 \\
\hline $\mathbf{x}$ & $p$-Coumaric acid & $\mathrm{C}_{9} \mathrm{H}_{8} \mathrm{O}_{3}$ & 21.48 & 164.047 & 163.1 & 327.1 \\
\hline $\mathbf{X I}$ & $\begin{array}{c}\text { 4-(1’-Hydroxy- } \\
\text { 1'-dimethyl) cy- } \\
\text { clohexa-1,3-diene-1 } \\
\text { carboxylic acid }\end{array}$ & $\mathrm{C}_{10} \mathrm{H}_{14} \mathrm{O}_{3}$ & 22.31 & 182.094 & 181.2 & 363.1 \\
\hline XII & $\begin{array}{l}\text { Kynurenic acid } \\
\text { tautomer }\end{array}$ & $\mathrm{C}_{10} \mathrm{H}_{7} \mathrm{NO}_{3}$ & 22.54 & 189.042 & 188.1 & 377.1 \\
\hline XIII & Gamma-Lact-3-PKA & $\mathrm{C}_{14} \mathrm{H}_{12} \mathrm{~N}_{2} \mathrm{O}_{2}$ & 24.32 & 240.089 & 239.1 & n.d. \\
\hline XIV & Kynurenic acid & $\mathrm{C}_{10} \mathrm{H}_{7} \mathrm{NO}_{3}$ & 30.62 & 189.042 & 188.1 & 377.1 \\
\hline
\end{tabular}

$\mathrm{R}_{\mathrm{t}}=$ retention time: *HPLC mobile phase-1: "HPLC mobile phase-2

n.d. $=$ not detected 
Table 2.

GC-EI-MS of aglycone polyphenolic and alkaloid compound TMS-derivatives detected in jujube

(Ziziphus lotus) honey

\begin{tabular}{|c|c|c|c|c|}
\hline No & $\begin{array}{l}\text { Polyphenolic } \\
\text { compound }\end{array}$ & $\begin{array}{c}\mathrm{R}_{\mathrm{t}} \\
\text { (min.) }\end{array}$ & $\begin{array}{l}\mathrm{M}^{+} \\
\text {calc. }\end{array}$ & $\begin{array}{l}\text { Major neutral fragments } \\
(\mathrm{m} / \mathrm{z} \%)\end{array}$ \\
\hline II & 4-Hydroxyquinoline & 16.38 & 217 & $\begin{array}{c}\text { 73(29), 101(13), } 172(18), 202(100), \\
217(49)\end{array}$ \\
\hline III & p-Hydroxybenzoic acid & 16.51 & 282 & $\begin{array}{c}73(74), 193(56), 223(71), 267(100), \\
282(28)\end{array}$ \\
\hline IV & trans-Caffeic acid & 29.30 & 396 & $\begin{array}{c}\text { 73(100),191(14), 219(7), 307(11), } \\
381(24), 396(99)\end{array}$ \\
\hline V & Kynurenic acid & 27.67 & 333 & $\begin{array}{c}\text { 73(85), } 231(81), 288(21), 304(34), \\
\text { 318(100), 333(10) }\end{array}$ \\
\hline VI & Methyl syringate & 21.30 & 284 & $\begin{array}{c}\text { 73(26), 223(24), 254(100), 269(46), } \\
284(31)\end{array}$ \\
\hline
\end{tabular}

Base peak $=$ bold

\section{DISCUSSION}

The polyphenol content $(11.73+0.50 \mathrm{mg} / \mathrm{kg})$ of Moroccan Jujube honeys compares favorably with those described for six Chinese (Cheng et al., 2014) Jujube honeys (2.49 mg/kg), which comprise six monophenolic acids including ferulic acid $(1.50 \mathrm{mg} / \mathrm{kg})$, chlorogenic acid and one diphenolic acid namely ellagic acid (0.37 $\mathrm{mg} / \mathrm{kg}$ ), and five wild Jujube commercial honey brands from UAE, Oman, Pakistan and Kashmir, evaluated within the framework of honeys from arid and non-arid regions (Habib et al., 2014). The mean value of total phenolic compounds in these five honeys was $0.92 \mathrm{mg} / \mathrm{kg}$ comprising gallic acid, vanillic acid, syringic acid, $p$-coumaric acid, ferulic acid, cinnamic acid, catechin, epicatechin and rutin. Badjah Hadj Ahmed et al. (2014) reported on the polyphenolic content of twelve Jujube honeys from various regions of the Yemen. The following twenty-three phenolic compounds were identified and quantitated in these honeys: the phenolic acids gallic acid, chlorogenic acid, p-hydroxybenzoic acid, p-hydroxyphenylacetic acid, caffeic acid, vanillic acid, syringic acid, $p$-coumaric acid, ferulic acid, sinapic acid; the flavonoids naringin, myricetin, quercetin, naringenin, kaempferol, apigenin, chrysin, galangin,y phenol, benzoic acid, cinnamic acid, thymol and carvacrol. The mean concentration of polyphenolic compounds detected in these Jujube honeys from the Yemen was 25.71 $\mathrm{mg} / \mathrm{kg}$ represented by phenolic acids (12.85 mg/ $\mathrm{kg})$, flavonoids $(7.49 \mathrm{mg} / \mathrm{kg})$ and other phenol compounds $(5.37 \mathrm{mg} / \mathrm{kg})$. The mean major polyphenol of each class in this report was $p$-hydroxybenzoic acid at $7.66 \mathrm{mg} / \mathrm{kg}$ or phenolic acids, chrysin at $0.50 \mathrm{mg} / \mathrm{kg}$ for flavonoids and cinnamic acid at $0.52 \mathrm{mg} / \mathrm{kg}$ for other phenols. The detection of alkaloids especially kynurenic acid, 4-hydroxquinoline and its glycoside as a major phytochemical class (58\%) in the Moroccan Jujube honeys was studied here. Kynurenic acid was reported (Truchado et al., 2009) to be a major alkaloid component of monofloral chestnut honey (over 70\%). Given that the Moroccan Jujube honeys also contained appeciable levels of alkaloids, we compared our data with that of chestnut (Castanea sativa Mill.) honey produced in Italy. The phytochemical content of this honey sample (Tab. 3) was dominated by alkaloids, especially kynurenic acid $(1246 \pm 17 \mathrm{mg} / \mathrm{kg})$. However the lackof evidence for the presence of 4-hydroxyquinoline (II) and its glycosylated derivative (I) in chestnut honey indicates that the polyphenolic profile of Jujube honey described in this paper appears to be unique and to differ from Jujube 
Table 3. Major polyphenolic compounds, alkaloids and terpenoids detected in Jujube honeys and Chestnut honey (Italy)

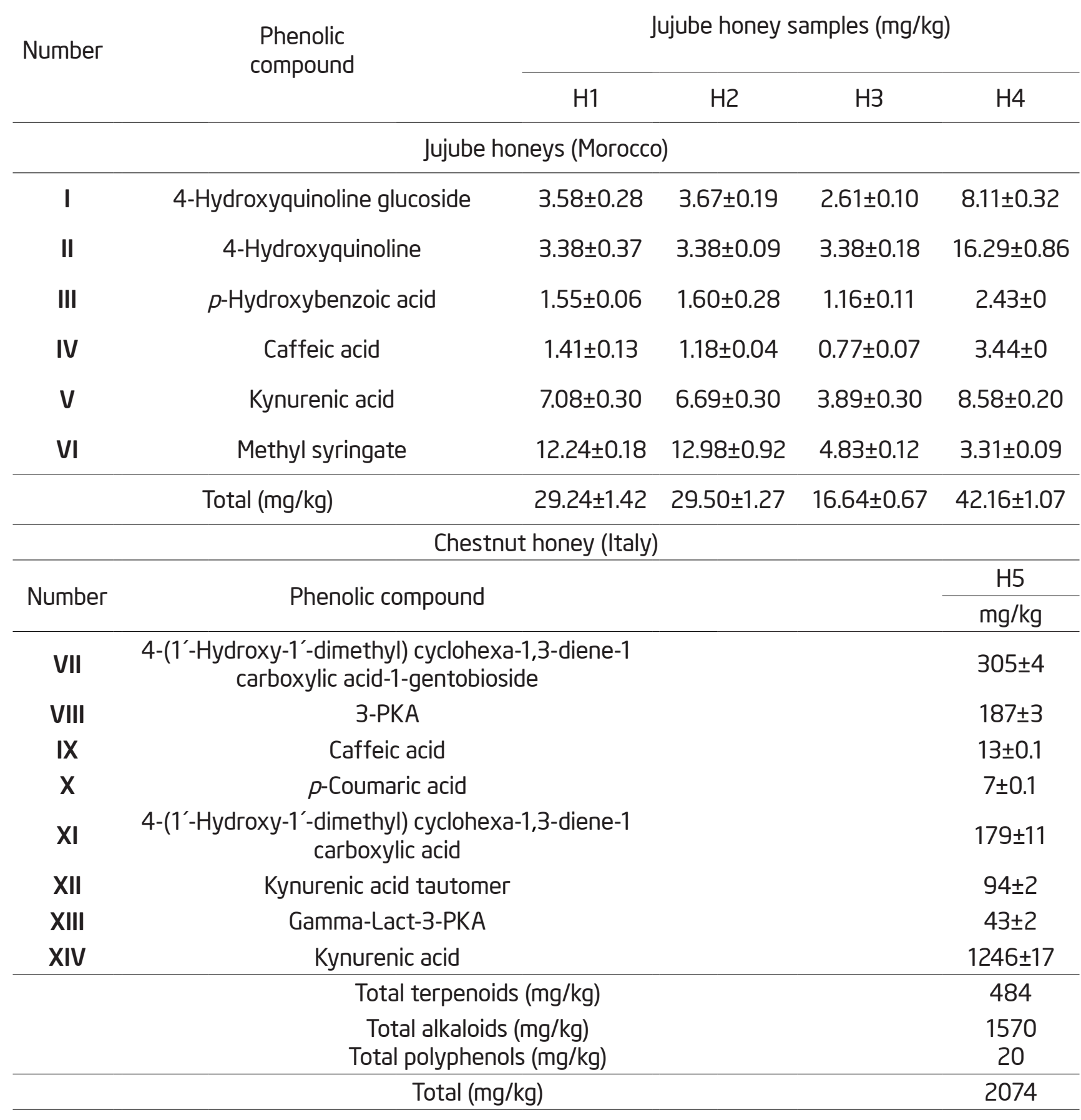

honeys studied of China, UAE, Oman, Pakistan, than reported those by Truchado, et al. (2009). Kashmir and Yemen. The presence of 3-PKA (187 $\pm 3 \mathrm{mg} / \mathrm{kg})$ and The levels of kynurenic acid (V) at $1246 \pm 17$ gamma-Lact-3-PKA (43 $\pm 2 \mathrm{mg} / \mathrm{kg})$ were also $\mathrm{mg} / \mathrm{kg}$ detected in the Italian chestnut honey detected. Truchado et al. (2009) identified were comparable to those (mean $=1161 \mathrm{mg} /$ and quantitated alkaloids in chestnut honeys $\mathrm{kg}$ ) reported by Beretta, et al. (2009) for eight for the first time. We can confirm that the tauItalian chestnut honeys, but around 3x higher tomerization (94 $\pm 2 \mathrm{mg} / \mathrm{kg}$ ) of kynurenic acid 
occurs based on its identical molecular weight and UV spectrum to that reported by Truchado et al. (2009) and that the major terpenoids are 4-(1'-dimethyl)cyclohexana-1,3-diene-1-carboxylic acid $(179 \pm 11 \mathrm{mg} / \mathrm{kg})$ and its gentobioside derivative (305 $\pm 4 \mathrm{mg} / \mathrm{kg}$ ).

The data presented in this report shows that the content of phenolic compounds detected in Moroccan Jujube honeys compares favourably with that of other countries. However, future larger studies incorporating Jujube honey samples from further Moroccan provinces are recommended. An evaluation of the potential health-benefits of Jujube honey extracts in comparison to a range of other monofloral honeys are also urgently recommended in a range of in-vitro antioxidant and cell culture assays as well as in preclinical models.

\section{ACKNOWLEDGMENTS}

The authors received no specific funding for this work.

\section{REFERENCES}

Aliferis, K.A., Tarantilis, P.A., Harizanis, P.C., \& Alissandrakis, E. (2010). Botanical discrimination and classification of honey samples applying gas chromatography/mass spectrometry fingerprinting of headspace volatile compounds. Food Chemistry, 127(3), 856-862. DOl: 10.1016/j. foodchem.2009.12.09

Asadi-Pooya, A.A., Pnjehshahin, M.R., \& Beheshti, S. (2003). The antimycobacterial effect of honey: an in vitro study. Rivista di Biologia, 96(3), 491-495.

Badjah Hadj Ahmed, A.Y., Obbed, M.S., Wabaidur, S.M., Al Othman, Z.A., Al-Shaalan, N.H. (2014). Highperformance liquid chromatography analysis of phenolic acid, flavonoid, and phenol contents in various natural Yemeni honeys using multi-walled carbon nanotubes as a solid-phase extraction adsorbent. Journal of Agricultural and Food Chemistry, 62(24), 5443-5450. DOl: 10.1021/ jf5011758
Benammar, C., Hichami, A., Yessoufou, A., Simonin, A.M., Belarbi, M., Allali, H., Khan, N. A. (2010). Zizyphus lotus L. (Desf.) modulates antioxidant activity and human T-cell proliferation. BMC Complementary and Alternative Medicine, 10, 54, doi: 10.1186/14726882-10-54

Beretta, G., Artali, R., Caneva, E., Orlandini, S., Centini, M., Facino, R.M. (2009). Quinoline alkaloids in honey: further analytical (HPLC-DAD-ESIMS, multidimensional diffusion-ordered NMR spectroscopy), theoretical and chemometric studies. Journal of Pharmaceutical and Biomedical Analysis, 503), 432-439. DOl: 10.1016/j.jpba.2009.05.029

Bogdanov, S., Ruoff, K., \& Oddo Persano, L. (2004). Physico-chemical methods for the characterisation of unifloral honeys - A Review. Apidologie, 35(1), 4-17. DOl: 10.1051/apido:2004047

Cernak, M., Majtanova, N., Cernak, A., \& Majtan, J. (2012). Honey prophylaxis reduces the risk of endophthalmitis during perioperative period of eye surgery. Phytotherapy Research, 26(4), 613-616. DOl: 10.1002/ptr.3606

Cheng, N., Zhao, H., Chen, S., He, Q., Cao, W. (2019). Jujube honey induces apoptosis in human hepatocellular carcinoma HepG2 cell via DNA damage, p53 expression, and caspase activation. Journal of Food Biochemistry, 43(11), el2998. DOl:10.1111/jfbc.12998

Cheng, N., Du, B., Wang, Y., Gao, H., Cao, W., Zheng, J., Feng, F. (2014). Antioxidant properties of Jujube honey and its protective effects against chronic alcohol-induced liver damage in mice. Food Function, 5(5), 900-908. D0l: 10.1039/c3fo60623f

Descottes, B. (2009). Cicatrisation par le miel, l'expérience de 25 ans. Phytothérapie, 72$), 112-116$. DOl: 10.1007/s10298-009-0378-7

Emad, M.A., \& Arafa H.I. (2019). Screening for antibacterial activity of two Jujube honey samples collected from Saudi Arabia. Journal of Apitherapy, 5(1), 6-9. DOl: 10.5455/ja.20190120035814 
Ghedira, K., Chemli, R., Caron, C., Nuzilard, J.-M., Zeches, M., Le Men-Olivier, L. (1995). Four cyclopeptide alkaloids from Zizyphus lotus. Phytochemistry, 38(3), 767-772. DOl: 10.1016/0031-9422(94)00669-K

Ghedira, K., Chemli, R., Richard, B., Nuzillard, J. -M., Zeches, M., Le Men-Olivier,L.(1993) Two cyclopeptide alkaloids from Zizyphus lotus. Phytochemistry, 32(6), 1591-1594. DOl: 10.1016/0031-9422(93)85186-U

Habib, H.M., Al Meqbali, F.T., Kamal, H., Souka, U.D., Ibrahim, W.H. (2014). Bioactive components, antioxidant and DNA damage inhibitory activities of honeys from arid regions. Food Chemistry, 153, 2834. DOl: 10.1016/j.foodchem.2013.12.044

Khallouki, F., Haubner, R., Erben, G., Ulrich, C.M., Owen, R.W. (2012). Phytochemical composition and antioxidant capacity of various botanical parts of the fruits of Prunus $\times$ domesticaL. from the Lorraine region of Europe. Food Chemistry, 133(3), 697-706. DOl: 10.1016/j.foodchem.2012.01.071

Khallouki, F., Haubner, R., Hull, W.E., Erben, G., Spiegelhalder, B., Bartsch., H., Owen, R.W. (2007). Isolation, purification and identification of ellagic acid derivatives, catechins, and procyanidins from the root bark of Anisophyllea dichostyla R. Br. Food and Chemical Toxicology, 45(3), 472-485. DOl: 10.1016/j.fct.2006.09.011

Truchado, P., Martos, I., Bortolotti, L., Sabatini, A.G., Ferreres, F., Tomas-Barberan, F.A. (2009). Use of quinoline alkaloids as markers of the floral origin of chestnut honey. Journal of Agricultural and Food Chemistry, 5713), 5680-5686. D0l: 10.1021/ jf900766v
Wang, J., Xue, X., Du, X., Cheng, N., Chen, L., Zhao, J., Zheng, J., Cao, W. (2014). Identification of Acacia honey adulteration with rape honey using liquid chromatography-electrochemical detection and chemometrics. Food Analytical Methods, 710), 2003-2012. DOl: 10.1007/s12161-014-9833-7

Zerrouk, S., Seijo, M.C., Escuredo, O., RodríguezFlores, M.S. (2017). Characterization of Ziziphus lotus (Jujube) honey produced in Algeria. Journal of Apicultural Research, 571), 166-174. DOl: 10.1080/00218839.2017.1399663

Zhao, J., Du, X., Cheng, N., Chen, L., Xue, X., Zhao, J., Wu, L., Cao, W. (2016). Identification of monofloral honeys using HPLC-ECD and chemometrics. Food Chemistry, 194, 167-174. DOl: 10.1016/j.foodchem.2015.08.010

Zumla, A., \& Lulat, A. (1989). Honey - a remedy rediscovered. Journal of the Royal Society of Medicine, 82(7), 384-385. https://doi. org/10.1177/014107688908200704 